ISSN 0719-7160

\title{
LIBERTAD DE CONCIENCIA Y RELIGIÓN EN EL PROCESO CONSTITUYENTE CHILENO
}

\author{
ESTEBAN QUIROZ GONZÁLEZ ${ }^{1}$
}

\begin{abstract}
Resumen:
Este artículo pretende realizar una breve descripción de la libertad religiosa en la historia y actualidad del derecho constitucional chileno a fin de determinar el estado y los desafíos en esta materia de cara a un eventual proceso constituyente, comparándolo con similares procesos en el contexto latinoamericano y en la discusión legislativa.

Palabras claves: proceso constitucional chileno, libertad de conciencia, libertad religiosa

\section{Abstract:}

This article intends to make a brief description of religious freedom in the history of Chilean constitutional law, in order to determine its current status and the challenges that must be faced in an eventual constituent process, comparing it with similar Latin Americans processes and their legislative discussions.
\end{abstract}

Key words: chilean constitutional process, freedom of conscience, religious freedom

DOI: $10.7764 /$ RLDR.9.113

\section{INTRODUCCIÓN}

En el marco de la reforma constitucional chilena, introducida por la Ley $N^{\circ} 21.200$ que modifica el capítulo XV de la Constitución y que redundará en un plebiscito orientado a iniciar un proceso para una nueva Constitución Política, preciso resulta estudiar y analizar la libertad de conciencia y de religión en nuestro sistema constitucional, a fin de determinar el rol de dichas libertades en la historia constitucional chilena, los elementos y desafíos de la regulación actual, las discusiones que vienen dándose en la materia dentro de nuestro país a nivel legal, y cómo el mismo

\footnotetext{
${ }^{1}$ Licenciado en derecho y abogado de la Universidad de Chile. Profesor ayudante en el curso de derecho administrativo en la facultad de derecho de la Universidad de Chile. E-mail: estebanquiroz91@gmail.com
} 
Esteban Quiroz González \& Alexandra Maldonado Carvajal: Libertad de conciencia y religión en el proceso constituyente chileno.

se ha desarrollado en los más recientes procesos latinoamericanos en el marco de lo que se ha denominado como el "nuevo constitucionalismo latinoamericano", de forma tal de tener un panorama completo sobre lo que podría ser la discusión en un eventual proceso constituyente, considerando siempre esta tensión moderna continua entre lo jurídico político y lo religioso.

\section{LA LIBERTAD RELIGIOSA EN LAS PRIMERAS CONSTITUCIONES CHILENAS}

Luego del periodo revolucionario independentista, y con la naciente República de Chile, existe aquello que los historiadores han denominado como "ensayos constitucionales". Con esto han querido referirse a los siete textos de naturaleza constitucional que se realizaron en un tiempo relativamente breve en los albores de nuestro Estado: las Constituciones de 1811, 1812, 1814, 1818, 1822,1823 y 1828.

La cuestión religiosa se manifiesta tempranamente en este periodo histórico, pues la Constitución de 1812, denominada "Reglamento Constitucional Provisorio del Pueblo de Chile" creado bajo el gobierno de José Miguel Carrera, señala en su artículo primero: "La religión católica, apostólica, es y será siempre la de Chile".

Dicha redacción de la cuestión religiosa desde luego está lejos de consagrar tal libertad, pero de todas formas generó polémica en el contexto de un Estado chileno recién independizado de la Corona española confesional católica romana: en primer lugar no señalaba que la iglesia fuera "romana" ni que quedaran expresamente prohibidas las otras religiones, por lo tanto en su época fue rechazada por la Iglesia Católica, acusando al texto de querer nacionalizar la iglesia al excluir a Roma, y de abrir una ventana para la tolerancia a los cultos disidentes ${ }^{3}$, es decir, abrir espacio a una cierta libertad religiosa ${ }^{4}$.

En la Constitución de 1818 se corrigió este elemento crítico de Carrera. En efecto, su Título II "De la Religión del Estado", Capítulo Único rezaba que: "La Religión Católica Apostólica Romana es la única y exclusiva del Estado de Chile. Su protección, conservación, pureza e inviolabilidad, será unos

\footnotetext{
2 (Sobre el "Nuevo constitucionalismo latinoamericano", 2018).

3 (Lagos Schuffeneger, 2009 pág. 30)

4 Se dice que está opción de José Miguel Carrera se debe a la influencia que tuvo sobre él el cónsul norteamericano y protestante Joel Roberts Poinsset. De hecho, en el escudo nacional propuesto por Carrera utiliza la frase latina "post tenebrax lux", emblema eminentemente reformado (Ortiz Retamal, 2017 pág. 129).
} 
ISSN 0719-7160

de los primeros deberes de los Gefes de la sociedad, que no permitirán jamás otro culto público, ni doctrina contraria á la de Jesucristo" (sic).

Naturalmente, la redacción de la Constitución de 1818 responde a la crítica de la Constitución de Carrera y reafirma la herencia colonial del naciente Estado chileno, consagrando a la Iglesia Católica Romana como iglesia oficial y excluyente, la que incluso debía ser protegida y conservada.

En la Constitución de 1822, promulgada por O’Higgins, este asunto se regulaba en el Título 2 "De la Religión del Estado", Capítulo Único, artículos 10 y 11, que versaba: "La Religión del Estado es la Católica, Apostólica, Romana, con exclusión de cualquiera otra. Su protección, conservación, pureza, é inviolabilidad es uno de los primeros deberes de los Jefes del Estado, como el de los habitantes del territorio su mayor respeto y veneración, cualquiera que sean sus opiniones privadas. Acto seguido, el artículo 11 señalaba: "Toda violación del artículo anterior será un delito contra las leyes fundamentales del país".

Como se puede observar, esta redacción -si bien es igualmente enfática en la oficialidad y exclusividad de la Iglesia Católica Romana y evidentemente no es una disposición que consagre la libertad religiosa-, sí establece una innovación que abre una puerta ligeramente a una cierta libertad religiosa, pues no obstante lo dispuesto, existe el derecho a tener opinión o pensamiento privado en forma expresa. Aquello es propio de la apertura de O'Higgins, dada su simpatía con el mundo protestante anglosajón tanto inglés como estadounidense ${ }^{5}$.

Derogada la efímera Constitución de 1822, en 1823 nace la llamada "Constitución moralista" o "Constitución de Egaña", la cual regula la religión en el artículo 10 diciendo: "La Religión del Estado es la Católica, Apostólica, Romana, con exclusión del culto y ejercicio de cualquiera otra". Asimismo

\footnotetext{
${ }^{5}$ O’Higgins, como revolucionario independentista y masón tenía sentimientos anticlericales y liberales, e invitó al pastor escocés, misionero y educador de tradición bautista Diego Thompson, para fundar escuelas dentro del país. Dicho misionero trabajó en la alfabetización mediante la lectura de la Biblia con la que buscaba encubiertamente introducir la fe protestante en Sudamérica. Asimismo, intentando favorecer las relaciones comerciales con Estados Unidos, O’Higgins creó el patio de los disidentes en el puerto de Valparaíso, donde los protestantes tenían presencia debido a las relaciones comerciales con el mundo anglosajón. El liberalismo y heterodoxia de O'Higgins al tolerar el protestantismo fue fuertemente criticado por el clero católico, así, el sacerdote franciscano José Javier de Guzmán advertía que era un detestable libertinaje que generaría apostasía entre los jóvenes que se levantarían para tomar armas, destruir templos y derribar el gobierno producto de la tolerancia religiosa (Cid, 2014 págs. 171-172).
} 
Esteban Quiroz González \& Alexandra Maldonado Carvajal: Libertad de conciencia y religión en el proceso constituyente chileno.

el artículo 11, al regular la ciudadanía, establece en el número 6 el requisito de ser "católico romano" para ser ciudadano.

Como se observa, se mantiene la oficialidad de la religión católica romana como exclusiva del Estado, eliminado lo establecido en la Constitución de O’Higgins que abría una pequeña puerta a la libertad de conciencia religiosa, eliminado cualquier referencia a la opinión privada, con un sentido totalizante que no distingue entre lo público y lo privado, sino que oficializa de forma amplísima a la religión del Estado y de los habitantes de la República. Egaña justificaría esta visión diciendo que "el pluralismo religioso terminaría necesariamente generando ingobernabilidad, inmoralidad e irreligión en la población, debilitando el poderío del Estado"

La Constitución de 1828, de carácter liberal y última de este periodo de ensayos, trae algunas innovaciones. Su capítulo primero titulado "De la nación" reza en su artículo $3^{\circ}$ : "Su relijion es la Católica Apostólica Romana, con esclusion del ejercicio público de cualquiera otra" (sic).

Salta a la vista la diferencia planteada en este texto constitucional con el anterior, pues ahora la religión católica apostólica romana no aparece como del Estado sino de la Nación, y si bien es exclusiva se elimina su sentido totalizante al establecer que en lo público lo es, abriendo una puerta a reconocer la disidencia al menos en privado. Se abre así un elemento claro en favor de una libertad de conciencia confinada al menos en la vida privada, la cual es reforzada por el artículo 12 de dicho cuerpo legal, que -regulando los derechos de las personas- establece que "Toda acción que no ataque directa o indirectamente a la sociedad, o perjudique a un tercero, está exenta de la jurisdicción del majistrado i reservado solo a Dios" (sic). Es decir, se establece un elemento liberal que abre, de a poco, la puerta a la libertad de conciencia y religión, estableciendo que aquello que no afecte a terceros escapa a la jurisdicción y propósito del derecho, cuestión propia del derecho moderno liberal.

Ahora bien, aunque estos ensayos constitucionales no pierden importancia para nuestra historia constitucional (en el contexto de una naciente República chilena que, desde luego, requiere de la legitimación religiosa mayoritaria para consolidarse ${ }^{7}$ ), sin duda que las constituciones más decisivas por su duración en Chile corresponden a las últimas tres Constituciones, a saber, la de 1833, la 1925 y la de 1980.

\footnotetext{
${ }^{6}$ (Cid, 2014 pág. 173)
}

${ }^{7}$ (Cid, 2014 pág. 169) 
ISSN 0719-7160

\section{LA CUESTIÓN RELIGIOSA EN LA CONSTITUCIÓN DE 1833}

La Constitución de 1833, que ha sido la Constitución de mayor duración temporal en la República, fue establecida luego de la victoria de los conservadores sobre liberales en la decisiva batalla de Lircay. Dicha Constitución -base del orden portaliano-, respecto a la cuestión religiosa estableció en su capítulo III, artículo 5 que: "La relijión de la República de Chile es la Católica Apostólica Romana, con esclusión del ejercicio público de cualquier otra" (sic).

Como se observa, a diferencia de la Constitución de 1828 la religión ya no es un asunto de la Nación sino nuevamente de la República, del Estado chileno, lo que marca un claro efecto de su visión conservadora y del uso legitimador que tuvo para el régimen portaliano, aunque mantiene una apertura tenue, en el tenor literal, a al menos el culto privado de otras religiones. En ese sentido, algunos autores como Simon Collier señalan que esta Constitución reclericaliza la sociedad ${ }^{8}$.

Sin embargo, a pesar de este marcado autoritarismo y fervor por el orden y uniformidad en la Carta de 1833 que buscaba la estabilización del orden estatal, la cuestión de la libertad religiosa se seguirá debatiendo en este periodo constitucional con gran intensidad (ver por ejemplo la cuestión del Sacristán y el profundo debate en materia de tolerancia religiosa ${ }^{9}$ ). A nivel constitucional surgiría un gran hito, cual es la polémica ley interpretativa de la Constitución de 27 de julio de 1865. Dicha ley, compuesta por dos artículos, señalaba que por el artículo $5^{\circ}$ de la Constitución de 1833 "se permite a los que no profesan la relijion católica, apostólica, romana, el culto que practiquen dentro del recinto de edificios de propiedad particular" (sic).

Asimismo, se señala en el artículo segundo que "Es permitido a los disidentes fundar y sostener escuelas privadas para la enseñanza de sus propios hijos en la doctrina de sus relijiones" (sic).

Tenemos pues aquí un reconocimiento de la disidencia religiosa dentro del territorio como realidad, y su derecho -al menos de forma particular y no pública- a ejercer su culto y enseñanza a sus hijos. Todo esto en un contexto eminentemente migratorio.

${ }^{8}$ (Cid, 2014 pág. 182)

${ }^{9}$ (Stuven, 2014 págs. 192-200) 
Esteban Quiroz González \& Alexandra Maldonado Carvajal: Libertad de conciencia y religión en el proceso constituyente chileno.

A nivel legal, surgen otras disposiciones que vienen a resolver problemas relativos a la libertad de culto, protagonizadas especialmente por el pueblo protestante o evangélico y grupos de élite anticlericales como la masonería, quienes lucharon por ideales liberales y progresistas buscando consagrar este derecho ${ }^{10}$, en aquel periodo histórico legislativo que se denominó como el de las leyes laicas ${ }^{11}$.

El primer gran hito ocurre el día 6 de septiembre de 1844, cuando se crea una ley que permite el matrimonio entre personas de religión no católica, sin la necesidad de comparecer ante un sacerdote de la Iglesia Católica. Dicha ley está orientada esencialmente a las colonias extranjeras no católicas, que tenían que casarse en embarcaciones fuera de la jurisdicción chilena o en los consulados de sus países previo a esta ley, de manera que este es un primer reconocimiento legal de la existencia de disidencia religiosa, aunque basada en una cuestión de corte migratorio ${ }^{12}$.

La tolerancia y libertad religiosa evidentemente no existía. Algunos historiadores señalan que el gobierno de Montt en 1852 reprimió fuertemente una manifestación por la libertad de conciencia ${ }^{13}$, sin embargo, cedió finalmente hacia mínimos de tolerancia al culto privado, permitiendo la construcción de un templo protestante, debido a la gran influencia económica e industrial de Inglaterra, con la cual buscaba mantener buenas relaciones como naciones civilizadas ${ }^{14}$.

El segundo gran hito se produce con la ley de cementerios laicos promulgada el 2 de agosto de 1883 , que permitió por fin a los disidentes religiosos acceder a ser enterrados en cementerios católicos, pues previo a esto no eran aceptados debido que se decía que profanaban los camposantos al no estar bautizados por la Iglesia Católica.

10 (Pereira García, 2016 págs. 143-149)

11 De acuerdo con (Ruiz-Tagle, 2016 pág. 105), a partir de 1870, producto de una serie de mutaciones constitucionales y de praxis política, existe, no obstante el tenor de la Constitución de 1833 una república liberal en Chile que dura hasta 1924. Esta tesis se fundamenta en la eliminación de prácticas autoritarias, mayor separación de poderes y un refuerzo del principio de legalidad, sin duda el reconocimiento del culto disidente en privado forma parte de esa liberalidad en la política chilena.

12 Por muchos años el Ministerio de Relaciones Exteriores chileno fue el "Ministerio de relaciones exteriores, culto y colonización", países como Argentina y Costa Rica que mantienen de hecho ciertos grados de oficialidad de la religión católica dentro de sus cartas fundamentales, mantienen también la cuestión del culto radicado en sus Ministerios de Relaciones Exteriores.

13 (Ortiz Retamal, 2017 pág. 55)

14 (El concepto de la tolerancia religiosa en Chile en la primera mitad del siglo XIX: a propósito de dos documentos diplomáticos británicos de 1854, 2019) 
ISSN 0719-7160

El tercer y quizá más importante hito se produce con la ley de matrimonio civil, aprobada el 27 de septiembre de 1883 y promulgada el 16 de enero de 1884, en virtud de la cual se separó el matrimonio religioso del civil. Antes estaba en manos de la Iglesia Católica, lo que generaba casos de discriminación en los que los sacerdotes no aceptaban los matrimonios mixtos entre católicos y no católicos $^{15}$, exigiendo abjurar a la fe o imponiendo restricciones en cuanto a la educación de los hijos $^{16}$. Dicha ley generó amplio repudio por parte del clero católico toda vez que el matrimonio es en la doctrina católica un sacramento que, de acuerdo con la argumentación de la época no puede ser separado del contrato civil ${ }^{17}$, además de generar reacciones que alertaban una persecución que estaría sufriendo la Iglesia Católica con este motivo con el que se aprobó una ley inmoral, se ofende a la religión, se implanta el ateísmo político y se expulsa a Dios del orden público ${ }^{18}$.

El cuarto hito que consolidó definitivamente estas reformas fue con la Ley que creó el Registro Civil, promulgada el 26 de julio de 1884, que vino a retirar de la Iglesia Católica las partidas de nacimiento que se realizaban al momento del bautismo, para fijar en funcionarios del Estado dicha labor, junto con las defunciones y los matrimonios. Se consolida así un camino de separación entre la Iglesia y el Estado y se da inicio también a su modernización administrativa y organizacional de este último $^{19}$, abriendo por tanto un periodo de reconocimiento a los derechos civiles de las minorías y disidencias religiosas, donde se encuentran protestantes, judíos, agnósticos, ateos y otras corrientes, y se da inicio a una separación al menos administrativa o funcionaria de la Iglesia Católica del Estado, pues las relaciones, reconocimientos y colaboraciones entre ambas se mantienen hasta hoy.

\section{LA CONSTITUCIÓN DE 1925: CONSOLIDACIÓN DE LA LIBERTAD DE CONCIENCIA RELIGIOSA EN LA TRADICIÓN CONSTITUCIONAL CHILENA.}

La Constitución de 1925 vino sin lugar a duda a poner fin al Estado Constitucional Nacional Católico ${ }^{20}$ expuesto en las Constituciones anteriores, consolidando a nivel de la Carta Fundamental lo iniciado por las así llamadas "leyes laicas" en el periodo constitucional anterior, con lo que se terminó

\footnotetext{
15 (Trumbull, 1863 pág. 6)

16 (Sepúlveda Rondanelli, 1993 pág. 55)

17 (Walker Martínez, 1889 pág. 164)

18 (Iglesia Católica, 1884 pág. 4)

${ }^{19}$ (Los inicios del registro civil de Chile: ¿̇Ruptura o continuidad con las antiguas partidas eclesiásticas?, 2014)

20 (El concepto de la tolerancia religiosa en Chile en la primera mitad del siglo XIX: a propósito de dos documentos diplomáticos británicos de 1854, 2019)
} 
Esteban Quiroz González \& Alexandra Maldonado Carvajal: Libertad de conciencia y religión en el proceso constituyente chileno.

de separar jurídicamente al menos la Iglesia Católica del Estado, estableciendo la libertad de culto como un derecho fundamental.

La Constitución de 1925 estableció lo siguiente en el artículo 10 número 2: "La Constitución asegura a todos los habitantes de la República: [...] 2. ${ }^{\circ}$ La manifestación de todas las creencias, la libertad de conciencia y el ejercicio libre de todos los cultos que no se opongan a la moral, a las buenas costumbres o al orden público, pudiendo, por tanto, las respectivas confesiones religiosas erigir y conservar templos y sus dependencias con las condiciones de seguridad e higiene fijadas por las leyes y ordenanzas. Las iglesias, las confesiones e instituciones religiosas de cualquier culto, tendrán los derechos que otorgan y reconocen, con respecto a los bienes, las leyes actualmente en vigor; pero quedarán sometidas, dentro de las garantías de esta Constitución, al derecho común para el ejercicio del dominio de sus bienes futuros. Los templos y sus dependencias, destinados al servicio de un culto, estarán exentos de contribuciones". También dicha Constitución, en sus disposiciones transitorias y ante el radical cambio producido en la institucionalidad, estableció una especie de indemnización para los sacerdotes católicos que eran mantenidos por el Estado.

De esta manera, aunque no lo señaló expresamente, el Estado chileno fue comprendido como uno laico. De acuerdo con autores como Salinas se trató de una "laicidad realista" ${ }^{21}$ que no suprimió la religión de la vida pública, sino que comprendió de todas formas su importancia dentro de ella, manteniendo privilegios a la Iglesia Católica (Botto, 2014 pág. 261) y con una fuerte cooperación económica basada en las exenciones tributarias, en los aspectos educacionales, en el uso de terrenos, en el acceso a capellanes católicos en las Fuerzas Armadas etc.

Esta nueva disposición constitucional que modernizó el Estado chileno fue una de las innovaciones más preponderantes de la Constitución de 1925 que en general reconoció libertades tan elementales como la de enseñanza o el propio derecho a reunión, juntamente con el reconocimiento de derechos sociales más amplios y el reconocimiento de la función social de la propiedad agregado a finales de la década del 60, que mantienen una fuerte influencia en el derecho chileno hasta hoy ${ }^{22}$. Dicha Constitución marcó el inicio de la libertad religiosa en nuestro país que no ha merecido cuestionamientos desde entonces, y coincide con el crecimiento de los antes "cultos disidentes" que pasaron a ser minorías religiosas con derecho constitucional a su respectiva libertad

${ }^{21}$ (Derecho y religión en la primera legislación chilena posterior a la libertad de cultos (1925-1939): del Estado confesional a la laicidad realista, 2016)

22 (Ruiz-Tagle, 2016 pág. 126) 
ISSN 0719-7160

de manifestación y de culto. Esto fue especialmente importante para el crecimiento protestante o evangélico ${ }^{23}$, particularmente en el movimiento pentecostal chileno, que registró su mayor crecimiento en forma coincidente con el reconocimiento de la libertad religiosa ${ }^{24}$.

\section{LA CONSTITUCIÓN DE 1980 Y LA LIBERTAD DE CONCIENCIA Y CREENCIAS}

La Constitución de 1980 es el resultado del golpe de Estado de 11 de septiembre 1973 que a través del Decreto Ley N¹28 atribuyó a la denominada Junta de Gobierno el poder constituyente y facultades para modificar, suspender y derogar la Constitución de 1925 estableciendo una nueva en su reemplazo. En ese contexto, se dictó el Decreto Supremo N¹.064 de 25 octubre de 1973, que ordenó a la Comisión de Estudios para la Nueva Constitución (Comisión Ortuzar) la elaboración de una nueva Carta que posteriormente fue revisada por el Consejo de Estado y luego por el General Augusto Pinochet, para su ratificación a través de un polémico plebiscito constitucional.

Luego de examinar la regulación existente en la Constitución de 1925, resulta llamativo observar que no tiene grandes diferencias con la Constitución vigente de 1980. En efecto, salvo detalles que trataremos, la Constitución del 80 es muy similar a la Constitución del 25 en estas materias, señalando su artículo 19 N 6: "La Constitución asegura a todas las personas: La libertad de conciencia, la manifestación de todas las creencias y el ejercicio libre de todos los cultos que no se opongan a la moral, a las buenas costumbres o al orden público. Las confesiones religiosas podrán erigir y conservar templos y sus dependencias bajo las condiciones de seguridad e higiene fijadas por las leyes y ordenanzas. Las iglesias, las confesiones e instituciones religiosas de cualquier culto tendrán los derechos que otorgan y reconocen, con respecto a los bienes, las leyes actualmente en vigor. Los templos y sus dependencias, destinados exclusivamente al servicio de un culto, estarán exentos de toda clase de contribuciones".

Las diferencias con el antiguo artículo 10 número 2 de la Constitución de 1925 son muy pequeñas y todas se basan en las observaciones del abogado miembro de la Comisión Enrique Evans, quien argumentó que "la libertad de conciencia" debe ir en primer lugar en la redacción del texto, toda vez que todos los demás derechos enumerados tienen su origen en ella, y propone ponerla

\footnotetext{
${ }^{23}$ (Salinas C, 1987 pág. 270)

${ }^{24}$ (Lalive d’Epinay, 2010 pág. 55)
} 
Esteban Quiroz González \& Alexandra Maldonado Carvajal: Libertad de conciencia y religión en el proceso constituyente chileno.

entonces al principio, antes de "la manifestación de todas las creencias", pues en la Constitución de 1925 estaba primero la manifestación de todas las creencias y luego la "libertad de conciencia". En segundo lugar, el mismo abogado, secundado posteriormente por el también miembro Sergio Diez, propone modificar la redacción del "ejercicio libre de todos los cultos que no se opongan a la moral, a las buenas costumbres o al orden público, pudiendo, por tanto, las respectivas confesiones religiosas erigir y conservar templos", eliminando el "por tanto", para establecer el derecho erigir y conservar templos luego de un punto seguido ${ }^{25}$. Su propósito era muy evidente pues señalaba que con la redacción de la Constitución de 1925, parecía que el resultado de la libertad de conciencia y manifestación de todos los cultos era solamente erigir templos, restringiendo así el derecho, cuando en realidad era más amplio, y por ende señala se establezca como quedó en la actual Constitución, con punto seguido, separando ambas ideas y no concibiendo como un aparente efecto único.

Adicionalmente, eliminó la frase "pero quedarán sometidas, dentro de las garantías de esta Constitución, al derecho común para el ejercicio del dominio de sus bienes futuros", pues se le consideró una aclaración que aparecía en la Constitución del 25 para resolver las dudas que se generarían transitoriamente ante la nueva situación religiosa del país inaugurada en dicha época.

Salvo estas pequeñas observaciones, esta relación de continuidad casi total entre la Constitución del 25 y la del 80 fue deliberada por los miembros de la Comisión de Estudios para la Nueva Constitución o "Comisión Ortuzar", según consta en las Actas, no queriendo los abogados miembros de la Comisión entrar en mayores debates que, en palabras de Jaime Guzmán, pueden "dilatar el trabajo", pues parecen estar de acuerdo con dicha disposición, la cual, lejos de todas las ardientes y apasionadas controversias generadas tanto en su creación como en la discusiones de la segundad mitad del siglo XIX, les parecen muy convenientes, patrióticas y ecuánimes.

\section{DISCUSIÓN EN LA COMISIÓN ORTÚZAR}

Sin embargo, una observación del abogado Alejandro Silva Bascuñán genera un interesante debate en el grupo de juristas, pues señala que se considera que la Iglesia Católica tiene una

\footnotetext{
${ }^{25}$ El acta señala que el señor Diez dice que esta modificación habría surgido en el proyecto de reforma
} constitucional de Eduardo Frei Montalva. 
ISSN 0719-7160

personalidad jurídica cuya naturaleza es de derecho público, lo que genera controversia en la discusión de la Comisión en torno a la naturaleza del resto de iglesias y confesiones religiosas ${ }^{26}$.

Los abogados miembros de la Comisión sostienen y dan por sentado -sin entrar en mayores detalles- que a la fecha de entonces existe una jurisprudencia muy clara por parte de los tribunales y además de un aparente acuerdo con la Santa Sede y el Presidente de la República de la época de la Constitución de 1925, don Arturo Alessandri Palma, y que se concretó a través del Arzobispo de Santiago de aquel tiempo, don Crescente Errázuriz, en torno a la naturaleza jurídica de derecho público de la Iglesia Católica $^{27}$, que, no obstante, no parece tan clara respecto del resto de confesiones religiosas que no parecen tenerla ${ }^{28}$.

Esta observación de Silva Bascuñán mueve al abogado Jorge Ovalle a proponer una modificación que reconozca expresamente la naturaleza jurídica de derecho público de las diversas confesiones religiosas y no solamente la católica. El presidente de la Comisión, Enrique Ortúzar da continuidad a esta observación diciendo: "¿O sería un poco aventurado entrar a reconocerles personalidad jurídica de derecho público a confesiones religiosas que no están adecuadamente cimentadas ni reguladas? Este punto, en verdad, quisiera verlo con un poco más de claridad. Porque, de no existir una razón perfectamente valedera, le parece que a esta altura del siglo XX no se deberían hacer estas diferencias, sobre todo cuando se está estableciendo el principio fundamental de reconocer la libertad de conciencia y el ejercicio libre de todos los cultos. ¿Por qué, entonces, mantener una discriminación en beneficio de una iglesia y en perjuicio de otras?

A esto, el abogado conservador Alejandro Silva Bascuñán responde: ¿por qué es indispensable, en este momento, mantener la personalidad jurídica de derecho público sólo para la

\footnotetext{
${ }^{26}$ De acuerdo con (Lagos Schuffeneger, 2005 pág. 23), la Iglesia Católica Ortodoxa Patriarcado de Antioquía gozaba de la calidad de persona jurídica de derecho público por gestión del presidente Salvador Allende, lo que consta en la ley $N^{\circ} 17.725$, publicada en el Diario Oficial el 25 de septiembre de 1972.

${ }^{27}$ Ver también (Botto, 2014 págs. 253-255)

28 Se discutió que el artículo 547 del Código Civil señala que las "iglesias" son personas jurídicas de derecho público, con lo cual podría entenderse que toda confesión religiosa tenía dicha calidad. Sin embargo, Jaime Guzmán lo refuta pues el Código de Bello, de 1855, se dictó bajo la Constitución de 1833 donde la religión oficial y excluyente era la católica, de forma tal que no se refería a todas las confesiones religiosas, sino que la intención era referir iglesias en el sentido de congregaciones específicas de la Iglesia Católica. Aquella consideración de Guzmán nos parece conforme a la realidad, pues las corporaciones religiosas no católicas funcionaban como corporaciones con las normas de derecho privado, por ejemplo, la Corporación Unión Evangélica (Iglesia Presbiteriana de Chile) o la Corporación Iglesia Metodista Pentecostal, etc.
} 
Esteban Quiroz González \& Alexandra Maldonado Carvajal: Libertad de conciencia y religión en el proceso constituyente chileno.

Iglesia Católica? Porque la personalidad jurídica de derecho público de la Iglesia Católica, al margen de aspectos puramente religiosos, tiene el fundamento de una solidez organizativa extraordinariamente fuerte; porque la personalidad jurídica de todas las instituciones comprendidas en la Iglesia Católica, deriva de la personalidad jurídica fundamental que ella tiene en su organización mundial. De manera que esa organización es la que da garantía para reconocerla. En nuestro ordenamiento jurídico, se está reconociendo a una institución que, desde el punto de vista jurídico, humano y natural, está suficientemente organizada y no creará problemas gravísimos como los que crearía al constituyente y al legislador si acaso se reconociera, de ligera, personalidad jurídica de derecho público a instituciones que, por aspectos puramente humanos y organizativos, no dan suficiente garantía. De tal modo que se lo está viendo y eso se explica, además, por varias razones históricas, que hacen que, en el plano mundial, sea la Iglesia Católica, la Santa Sede reconocida como personalidad jurídica de derecho público. De manera que eso les da a todos los chilenos, como a otros pueblos, la seguridad de que, desde el punto de vista jurídico, es una cosa bien organizada.

De modo tal que, desde el punto de vista humano, técnico, considera que sólo la Iglesia Católica, en este momento, debe ser consagrada como persona jurídica de derecho público, sin perjuicio de que, en un momento determinado, el constituyente o el legislador, al estudiar la organización de otra iglesia, considere que tiene tal grado de madurez, de cimiento y de solidez, desde el punto de vista jurídico, que merece la calidad de persona jurídica de derecho público.

En esta materia se produce un frondoso y al parecer inesperado debate, donde incluso se sugiere por parte de Jaime Guzmán elevar comunicaciones con el gobierno, sin embargo, el abogado Enrique Evans se opone a este cuestión señalando que "el peor "presente griego" que se le podría hacer al Presidente de la República, hoy día agobiado por problemas que todos saben que son enormes, sería que se le invitara, siquiera por vía indirecta, a considerar un nuevo trato o un nuevo estatuto entre el Estado y las iglesias." (sic).

Por su parte, el abogado Silva Bascuñán sugiere que la determinación de la naturaleza jurídica de derecho público podría quedar sujeta a una ley y no zanjada constitucionalmente. Jaime Guzmán señala estar de acuerdo con esta visión, mientras apunta a no entrar en un debate que no genera ventajas, pero sí muchos inconvenientes y controversias.

Con posterioridad, las actas registran la visión del abogado liberal Gustavo Lorca Rojas, quien entra en debate con Silva Bascuñán, realizando una fuerte argumentación en favor de la igualdad 
ISSN 0719-7160

religiosa manifestada en el igual reconocimiento de la calidad de personas jurídicas de derecho público como una cuestión de justicia e igualdad mínima.

Lorca argumenta que el respeto por la Iglesia Católica no se debe a las relaciones internacionales ni a que sea un sujeto de derecho internacional como arguyen algunos abogados de la Comisión, sino del respeto a la práctica religiosa en sí, de ser una iglesia que reúne a chilenos que buscan un perfeccionamiento espiritual, por último, del respeto al ejercicio de todos los cultos y a su supuesto, la libertad de pensamiento y de conciencia, por lo tanto, arguye, "del mismo modo se debe respetar las demás".

Respecto al argumento sobre que la Iglesia Católica está organizada jerárquica y disciplinadamente en forma autoritaria y tiene una estructura sólida; que no puede ocurrir lo mismo con las iglesias más débiles, porque esto puede contribuir a crear problemas y a generar abusos, Lorca señala que "Ia Iglesia Católica debe respetarse por lo que es y no por su fortaleza porque, si ésa fuera la razón, muchos mejores argumentos existen para que el Estado de Chile respete y proteja las más débiles, ya que son ésas las que necesitan protección... El respeto y el reconocimiento que la Constitución debe darle nace precisamente, de la debilidad de las demás iglesias, que sí necesitan, para su desarrollo integral, de este respeto o protección."

Recuerda, a continuación, que después el señor Silva Bascuñán expresó: “¿Y si las demás iglesias, o cualquiera de estas pequeñas iglesias, se transforman en algo peligroso para el Estado o en algo que no deba aceptarse?" a ello el abogado Lorca responde que aquella afirmación es extraordinariamente grave "porque supone que en el actual sistema, si una iglesia se estima contraria a los intereses del Estado en un momento dado, basta un procedimiento muy fácil, que es la cancelación de su personalidad jurídica. Y eso sí que es extraordinariamente peligroso. ¿'Por qué? La razón es evidente. El señor Silva Bascuñán manifestó que el Estado no se va a poder proteger contra estas iglesias. ¿Y por qué lo dijo? Porque él entiende que actualmente el Estado se puede proteger a través de este procedimiento, en cuya virtud se cancela la personalidad jurídica" ...

Esta discusión dentro de la Comisión es muy relevante, pues aunque de acuerdo con las actas no parecen tenerlo en cuenta de forma directa, dicho asunto era y sería vital para las confesiones religiosas no católicas en la época y contexto de la dictadura cívico militar, pues dicho gobierno dictó normas y empleó prácticas con las que afectó la libertad religiosa en tanto todas las confesiones 
Esteban Quiroz González \& Alexandra Maldonado Carvajal: Libertad de conciencia y religión en el proceso constituyente chileno.

religiosas que no fueran la Católica (y la Católica Ortodoxa del Patriarcado de Antioquía) eran "personas jurídicas de derecho privado".

En efecto, en marzo de 1974 se había dictado el decreto ley №349, que modificado por el decreto ley N¹.623 de 1976, establecía fuertes formas de vigilancia a las corporaciones de derecho privado, pues no solo les impidió realizar elecciones en sus directivas (artículo 1) sino que además establecía una expresa vigilancia a sus reuniones directivas por parte del Ministerio del Interior (artículo 4), además que por efecto del artículo $6^{\circ}$ inciso final, los Intendentes tenían, en virtud del artículo 2 de dicho decreto, la facultad de nombrar a los miembros de sus directivas cuando alguno "por imposibilidad física, moral o por cualquier otro motivo... no pudieran desempeñar definitivamente sus funciones". No solo eso, de acuerdo con el artículo $3^{\circ}$ los Intendentes tenían facultad para pedir la renuncia a cualquier directivo e incluso para removerlo del cargo si continuaba ejerciendo funciones, por realizar cualquier clase de "propaganda política", lo que se sancionaba con presidio menor en su grado mínimo.

Asimismo, por medio del decreto ley $\mathrm{N}^{\circ} 1183$ de septiembre de 1975 , se establecieron severas vigilancias a los dineros de las corporaciones privadas, incluyendo también los dineros que provinieran desde el extranjero, cuestión que fue denunciada como un intento por controlar "los fondos de las instituciones religiosas que animan la defensa de los derechos humanos" 29 como fueron organizaciones como la Fundación de Ayuda Social de las Iglesias Cristianas compuestas por diversas iglesias, que recibía la mayor parte de sus fondos de organismos internacionales tales como el Consejo Mundial de Iglesias. ${ }^{30}$

Esto es, durante el gobierno dictatorial se dictan normas para la vigilancia directa de todo tipo de organizaciones civiles, entre las que cabían las corporaciones de derecho privado que eran las que daban ropaje jurídico a las confesiones religiosas minoritarias no católicas, pues ésta última contaba con otro ropaje jurídico cual era la calidad de persona jurídica de derecho público.

De acuerdo con autores como Humberto Lagos ${ }^{31}$, dichos decretos aparecen precisamente cuando comienzan a levantarse ciertas voces críticas a la dictadura en el seno de algunas iglesias, y Ilegaron a operativizarse de forma directa en enero de 1976, cuando el Intendente de Santiago

\footnotetext{
${ }^{29}$ (Lagos Schuffeneger, 1988 pág. 226)

30 (Bastías Saavedra, 2013 págs. 104-116)

${ }^{31}$ (Lagos Schuffeneger, 1988 pág. 223)
} 
ISSN 0719-7160

invalidó la elección democrática de los directivos de la Convención Nacional Bautista (Iglesias Bautistas) y procedió a nombrarlos por decreto. Misma cosa aconteció cuando el Intendente Regional, general de brigada aérea don Enrique Ruiz, con fecha 27 de octubre de 1977, empleando dicho decreto, solicitó la renuncia a la Directiva de la Iglesia Luterana en el contexto del cisma sufrido por ella luego que el obispo Helmut Frenz participara activamente en la defensa de los derechos humanos.

En este entendido, resulta manifiesto que esta diferencia entre personas jurídicas de derecho público y privado no eran meramente teórica, sino anclada precisamente en un contexto sociopolítico donde el diferente trato ponía en cuestión la libertad e igualdad religiosa dentro del Estado chileno.

A la postre, la Comisión termina razonando, al menos en forma mayoritaria, que en realidad la Constitución de 1925 no realiza tal distinción en forma expresa, sino que es posible interpretar que de hecho les reconoce a todas las iglesias la calidad de persona jurídica de derecho público, si bien por una cuestión práctica el Ministerio de Justicia debe registrarlas en el área de corporaciones privadas, por lo cual termina imponiéndose mantener la norma de 1925 con las modificaciones meramente formales de redacción propuestas por el abogado Evans y Diez, y de donde proviene nuestra actual norma constitucional, que -en esta materia- ha permanecido indemne y sin modificaciones desde entonces.

\section{PROBLEMAS EN LA CONSTITUCIÓN DE 1980}

Evidentemente, la Constitución del 80 mantiene varios elementos críticos más que heredó de la Constitución de 1925, y que han sido señalados por Precht ${ }^{32}$, en términos de no señalar que se recoge expresamente la libertad religiosa, ni la objeción de conciencia ${ }^{33}$ y la libre formación de la misma, a los cuales pudiéramos agregar otros como la falta expresa del derecho a no tener religión alguna, a su manifestación tanto individual como colectiva, o la falta de referencia a la libertad y reconocimiento de las cosmovisiones indígenas.

\footnotetext{
32 (Precht Pizarro, 2006 págs. 21-40)

${ }^{33}$ El Tribunal Constitucional, en el polémico fallo de aborto tres causales, determinó de forma hermenéutica que este derecho existiría (ver considerando centesimotrigésimo y siguientes), incluso para personas jurídicas, atribuyéndose la facultad dicho tribunal de crear disposiciones legales dentro de dicho proyecto.
} 
Esteban Quiroz González \& Alexandra Maldonado Carvajal: Libertad de conciencia y religión en el proceso constituyente chileno.

No obstante, es preciso tener en cuenta que en virtud del artículo $5^{\circ}$ inciso segundo de la Constitución Política de la República, el derecho internacional de los derechos humanos bien puede ser invocado como parte integrante de la Carta Fundamental. En ese entendido la Declaración Universal de Derechos Humanos en su artículo 18 agrega la libertad de religión, expresando que incluye la libertad de cambiar de religión o creencia, reconociendo su manifestación tanto individual como colectivamente y tanto en público como en privado; asimismo el Pacto Internacional de Derechos Civiles y Políticos establece en su artículo 18 esos mismos elementos y agrega por supuesto el derecho a no ser objeto de medidas coercitivas que puedan menoscabar la libertad de tener o de adoptar la religión o creencias a elección de las personas, y la garantía que tendrían los padres y tutores legales para garantizar que los hijos reciban educación religiosa y moral de acuerdo con sus propias convicciones; mientras que la Convención Americana sobre Derechos Humanos, en su artículo 12 redunda sobre estos mismos elementos que parecen faltar de forma expresa en la Constitución del 80, y la Convención de los Derechos del Niño establece también el derecho a libertad religiosa y de conciencia de niños y niñas, el cual debe ser ejercido -en el espíritu de dicho cuerpo normativo- teniendo en cuenta su autonomía progresiva y el interés superior de niños, niñas y adolescentes ${ }^{34}$.

\section{EL ROL DE LA LEY N¹9.638 DE 1999}

Ahora bien, como es conocido, en 1999, y luego de años de insistencia principalmente por parte de grupos evangélicos y protestantes ${ }^{35}$, se dicta la ley 19.638 que establece normas sobre la constitución jurídica de las iglesias y organizaciones religiosas, también denominada "ley de culto". En virtud de ella se establece una vía legal, no constitucional, para reconocer la calidad de persona jurídica de derecho público a iglesias y organizaciones religiosas, subsanando casi dos décadas después esta diferencia, si bien en el rango de una ley ${ }^{36}$.

\footnotetext{
${ }^{34}$ Ver más en (El concepto de libertad religiosa en algunos instrumentos internacionales sobre derechos humanos que vinculan jurídicamente al Estado de Chile, 2008)

35 (Del Picó, 2013 pág. 100)

${ }^{36}$ Interesante resulta la crítica de (Lagos Schuffeneger, 2005 pág. 36), sobre que en realidad las Iglesias y Organizaciones Religiosas no deben ser de derecho público pues, según el autor, 1. No se corresponde con un estado laico, 2. No persiguen un fin público. 3. No procede respecto de ellas controles estatales propios de los entes públicos, 4. No son autoridad oficial, 5. El Estado no contribuye a su sostenimiento. De esta forma, Lagos señala que esta solución es una innovación legislativa chilena. Otros autores, como Jorge del Picó señalan que el efecto de la constitución de persona jurídica de derecho público no es otra cosa que el reconocimiento de la igualdad religiosa y la autonomía, sin que por ello pueda realizarse un trato discriminatorio a las entidades que conservan la persona jurídica de derecho privado (Del Picó, 2013 pág. 126).
} 
ISSN 0719-7160

La ley №19.638, asimismo, no solamente regula la constitución como personas jurídicas de las iglesias como señala en su título, sino que además establece algunas regulaciones que dan contenido a la garantía del artículo $19 \mathrm{~N}^{\circ} 6$. A saber, señala en su artículo $1^{\circ}$ que reconoce la "libertad religiosa y de culto en los términos de la Constitución Política de la República de Chile", redacción llamativa pues, como se señaló, la Carta Fundamental del 80 no habla expresamente de "libertad de religiosa y de culto". Asimismo, en el artículo $6^{\circ}$ y $7^{\circ}$ regula y define este concepto de "libertad religiosa y de culto", a partir de las facultades que la misma entrega a toda persona (artículo 6), y a toda "entidad religiosa" (artículo 7), es decir tanto individual como colectivamente.

Así, en virtud del artículo 6, para la persona o individuo, se establece la facultad de profesar la creencia religiosa que se escoja libremente, incluyendo el derecho a no profesar ninguna, a cambiarla o abandonarla, estableciendo el derecho a manifestarla o abstenerse de ello; explicitando la facultad de practicar en público o privado, individual o colectivamente actos de oración o culto, conmemorar festividades, celebrar ritos, observar día de descanso semanal, recibir una sepultura digna sin discriminación, no ser obligado a practicar actos de culto o recibir asistencia religiosa contraria a sus convicciones y a recibir asistencia religiosa donde quiera que se encuentre, lo que incluye recintos públicos como hospitales, cárceles o lugares de detención o en las Fuerzas Armadas; recibir e impartir enseñanza o información religiosa para sí o para los menores no emancipados o incapaces bajo su tuición y cuidado; además de reunirse o manifestarse públicamente con fines religiosos, reconociendo el derecho de asociarse para desarrollar actividades religiosas.

Mientras que las entidades religiosas (artículo 7) se establece autonomía para el desarrollo de sus propios fines, con especial énfasis en su el ejercicio del ministerio, practicar el culto, celebrar reuniones y fundar lugares para ello, además de establecerse facultades para determinar su estructura interna, jerarquía, cargos, capacitación, además de enunciar, comunicar y difundir su propio credo o doctrina.

En este entendido, la ley 19.638 con toda claridad regula más que la simple forma de constitución de personas jurídicas de derecho público para las entidades religiosas, estableciendo una igualdad de naturaleza jurídica con la histórica y predominante presencia de la Iglesia Católica, sino que además intentar cubrir por una vía legal algunos de los vacíos del constituyente del 80, en materia de la específica garantía no expresa de la "libertad religiosa", agregando algunos elementos 
Esteban Quiroz González \& Alexandra Maldonado Carvajal: Libertad de conciencia y religión en el proceso constituyente chileno.

que ya observábamos en los tratados internacionales de derechos humanos y que se extrañan en nuestra Carta Fundamental. Una vía al menos confusa para suplir una omisión en la Constitución vigente sobre un concepto que la misma parece desconocer, sobre todo si se tiene en cuenta la muy distinta jerarquía de ambos cuerpos normativos. En este entendido parece evidente la necesidad de corregir esta discrepancia, reconociendo con rango constitucional expreso "la libertad religiosa".

\section{ELEMENTOS A TENER EN CUENTA SOBRE EL PROCESO CONSTITUCIONAL EMANADO DE LA LEY N² 21.200}

A partir de la reforma constitucional de 24 de diciembre de 2019, corregida por la ley $\mathrm{N}^{\circ}$ 21.221 de 26 de marzo de 2021, y antecedida por un acuerdo transversal de diversos partidos políticos que se originó en una crisis profunda crisis institucional y de representatividad política que alcanzó su clímax en una serie de protestas por parte de la ciudadanía a partir del 18 de octubre de 2019, se estableció una vía institucional, legal, pacífica y democrática para resolver la crisis, que consiste en un inédito proceso participativo tendiente a la eventual creación de una nueva Carta Magna.

Eventual, por cuanto el proceso mismo mantiene una serie de etapas que establecen la creación y aprobación de una nueva Constitución solo como uno de los resultados posibles. La primera etapa sería la realización de un plebiscito que tendría lugar el 25 de octubre de 2020 en el que se aprobará o rechazará un proceso para una nueva Constitución, esto es, se aprobará o rechazará por parte de la ciudadanía que se realice una elección de representantes, también llamada Convención, que podrá tener dos modalidades a elegir también en dicho plebiscito, esto es, Convención Mixta, compuesta por miembros del poder legislativo y por miembros electos específicamente para ella; o Convención Constituyente, compuesta exclusivamente por miembros electos para este fin, sin presencia de diputados o senadores en ejercicio.

Dicha elección de representantes (que se realizaría el 11 de abril de 2021), reuniría a las personas que se encargarían de redactar una nueva Constitución Política en un plazo de 9 meses, prorrogable por otros 3, la que a su vez, una vez finalizada y dotada de contenido por los Convencionales Constituyentes electos para dicho fin, tendrá que ser aprobada por un nuevo plebiscito, esta vez de voto obligatorio para la ciudadanía, a realizarse sesenta días después del decreto del Presidente que llama a este plebiscito. 
ISSN 0719-7160

Dicho proceso, de carácter eminentemente procedimental y formal para dar luz o no a una Nueva Constitución Política, tiene algunos elementos de fondo al tenor del artículo 135 que deben ser considerados y que permiten hablar de un proceso constituyente tutelado o controlado por la Constitución vigente y su institucionalidad.

El primero y más elemental es que mientras se realiza, el mismo no suspende, restringe ni deroga la Constitución de 1980, sino que esta perderá su efecto solo si se aprueba el nuevo texto constitucional a través del segundo plebiscito respectivo, produciendo así un proceso constituyente bajo la observancia de la Constitución actual, lo que da a lugar a que ninguna de las garantías constitucionales ni instituciones democráticas será suspendida durante el proceso de elaboración de la nueva Constitución.

El segundo elemento radica en que la Convención no podrá atribuirse la soberanía, la cual, al tenor del artículo 5 de la actual Constitución, reside en la Nación, y no podrá tampoco atribuirse funciones diversas a la de la creación de un nuevo texto constitucional a ser aprobado por la ciudadanía, por ejemplo, no podrá derogar o crear nuevas leyes, es decir, se mantiene la juridicidad y legalidad mientras el texto se está creando.

Por último, dicho proceso tiene limitaciones mínimas de contenido en términos de mantener al Estado Chileno como una República con régimen democrático, debiendo respetar los tratados internacionales ratificados por Chile y que se encuentran vigentes. En ese sentido, debe someterse en grandes rasgos a la tradición constitucional chilena y a sus obligaciones internacionales, donde resulta evidente la preponderancia de los tratados internacionales de derechos humanos.

Así, desde el punto de vista de los derechos fundamentales, y en particular de la garantía de la libertad de conciencia y de culto o religión, el poder constituyente del proceso es refrendado por la observancia de valores democráticos básicos y de garantías fundamentales, por lo tanto, impide que se vaya a suspender durante la realización el derecho de libertad de conciencia y de manifestación de todos los cultos o que se vaya a derogar por parte de la Convención alguna ley relativa a la materia, y en cuanto al texto final, le indica la necesidad de respetar en su contenido derechos fundamentales, entre los que se incluye por supuesto la libertad de conciencia y la libertad religiosa. 
Esteban Quiroz González \& Alexandra Maldonado Carvajal: Libertad de conciencia y religión en el proceso constituyente chileno.

Ahora bien, más allá de estos elementos formales y de fondo, lo cierto es que el contenido de una eventual nueva constitución dependerá final y específicamente de las personas que a este efecto sean electas de forma democrática y participativa por la ciudadanía que podrá escogerlos en un proceso inédito en nuestra historia constitucional, con el evidente peso histórico de la rica tradición constitucional que revisábamos anteriormente. Por eso, para poder abundar sobre la libertad de conciencia en un eventual proceso constituyente no solo se debe tener en cuenta nuestro pasado local, sino también recurrir a las recientes experiencias de los países vecinos y por supuesto a las últimas tentativas de reformas constitucionales en el plano local, cuestión que veremos a continuación.

\section{PROCESOS CONSTITUCIONALES LATINOAMERICANOS COMPARADOS}

Evidentemente, el derecho comparado también nos ofrece elementos para comprender la temática de la libertad de conciencia y religión en un eventual proceso constitucional chileno, siendo relevante observar lo sucedido en los procesos latinoamericanos más recientes que se han realizado por la vía de asambleas constituyentes, referéndums o convenciones, que tienen indudables similitudes a la vía por la cual se realizaría el proceso chileno.

De esta manera, podemos observar los procesos acaecidos en nuestra región tales como Bolivia 2009, Ecuador 2008, Venezuela 1999 y Argentina 1994, que en sus muy diversos contextos sociopolíticos, económicos y culturales, trataron el tema de la libertad de conciencia y religión o la separación o no entre Iglesia y Estado. Revisamos a continuación brevemente y a grandes rasgos dichos procesos, poniendo especial énfasis en cómo evolucionó cada Carta Magna en estas materias, es decir, observando la diferencia que se produjo con las Constituciones actuales respecto de sus antecesoras, con el fin de observar una tendencia en ellas a mantener, restringir o aumentar dichas libertades.

\section{BOLIVIA}

Bolivia tuvo un referéndum Constitucional a inicios del año 2009, fecha en la que se aprobó por parte del pueblo la Constitución actualmente vigente. Esta fue promulgada y publicada el 7 de febrero de 2009, y desde esa fecha entró en vigencia. 
ISSN 0719-7160

Esta Carta Magna se compone de 411 artículos, sin contar preámbulo, disposiciones transitorias, abrogatoria ni final.

Su Constitución trata ampliamente la libertad religiosa, de manera de garantizarla como un derecho civil, como patrimonio cultural, e incluso como un derecho colectivo, siempre desde una perspectiva pluralista que en lugar de eliminar lo religioso intenta incluir perspectivas amplias hacia dicho fenómeno. Sin ir más lejos, en el preámbulo se habla de la "sagrada Madre Tierra", se agradece a "Dios", y se destaca la fortaleza de "nuestra Pachamama", algo propio de la noción de Estado Plurinacional que introduce dicha Carta.

Ya en su artículo 4, y dentro de las bases fundamentales del Estado, la Constitución de 2009 afirma que el Estado de Bolivia respeta y garantiza la libertad de religión y de creencias espirituales, de acuerdo con sus cosmovisiones. Señala directamente que el Estado es independiente de la religión.

Cuando se tratan los derechos fundamentales y las garantías de las personas, la Constitución señala en su artículo 14 numeral dos el principio básico de no discriminación. En ese contexto, indica que el Estado prohíbe y sanciona toda forma de discriminación fundada en razón de sexo, color, edad, orientación sexual, identidad de género, origen, cultura, nacionalidad, ciudadanía, idioma, credo religioso, ideología, filiación política o filosófica, estado civil, condición económica o social, tipo de ocupación, grado de instrucción, discapacidad, embarazo, u otras que tengan por objetivo o resultado anular o menoscabar el reconocimiento, goce o ejercicio, en condiciones de igualdad, de los derechos de toda persona. Nos interesa destacar también el artículo anterior que agrega la obligatoriedad de los tratados internacionales de Derechos Humanos ratificados por el Estado.

La libertad de conciencia y de culto también está garantizada como derecho civil. Así, el artículo 21 en su numeral 3 garantiza la libertad de pensamiento, espiritualidad, religión y culto, expresados en forma individual o colectiva, tanto en público como en privado, con fines lícitos. Se refuerza también como derecho colectivo, al garantizar (en su nomenclatura) a las naciones y pueblos indígena originario campesinos el goce del derecho a su identidad cultural, creencia religiosa, espiritualidades, prácticas y costumbres, y a su propia cosmovisión (artículo 30 II N²). 
Esteban Quiroz González \& Alexandra Maldonado Carvajal: Libertad de conciencia y religión en el proceso constituyente chileno.

La Carta Magna en comento mantiene un especial énfasis en la educación, interculturalidad y derechos culturales, dedicándoles un capítulo completo. Dentro de este punto llama la atención la importancia que se le da a la libertad de conciencia y de fe, asegurando que los centros educativos deberán reconocerlas y garantizarlas, así como también la enseñanza de religión, la espiritualidad de las naciones y pueblos indígena originario campesinos, y el fomento del respeto y la convivencia mutua entre las personas con diversas opciones religiosas, sin imposición dogmática. La propia Constitución asegura que en estos centros no se discriminará en la aceptación y permanencia de las alumnas y los alumnos por su opción religiosa. Además, se reconoce y respeta constitucionalmente el derecho de administración de entidades religiosas sobre unidades educativas que funcionen bajo la tuición de las autoridades (artículos 86 y 87).

Su Constitución contiene un apartado relativo a las culturas. Así, en su artículo 99 reconoce como parte del patrimonio cultural boliviano, la riqueza procedente del culto religioso y del folklore.

Es interesante destacar el amplio rol que juega la libertad de conciencia, de religión, de culto, de pensamiento y de espiritualidad en la Constitución y, por tanto, en la sociedad boliviana, observándose un análisis que es bastante completo relativo a esta garantía incluyendo la posibilidad de ejercerla en público, en privado, como parte de la educación, como un derecho colectivo, sin discriminación, sin perjuicio de establecerse claramente en su artículo 4 que el Estado es independiente de la religión. Es decir, el Estado de Bolivia no es confesional, pero garantiza y fomenta el ejercicio de la libertad religiosa, y debe hacerlo sin discriminación, es decir una laicidad que no suprime a lo religioso, sino que con independencia lo reconoce y fomenta (Cavieres 114). Antes de este referéndum el estado de Bolivia era confesional, reconociendo la religión católica, apostólica y romana como su religión oficial, y limitándose a garantizar el ejercicio público de cualquier otro culto, de enseñanza religiosa, a no discriminar a causa de la religión, y a mantener la riqueza del culto religioso como tesoro de la nación (artículos 3, 6, 182 y 191 de la Constitución Política del Estado de 1967). Sin ir más lejos, estando vigente esta Constitución Política entró en vigencia la ley de "libertad religiosa, organizaciones religiosas y de creencias espirituales", que tuvo por objeto establecer un marco jurídico de derechos y deberes para el ejercicio de la libertad religiosa y de creencias espirituales de acuerdo a sus cosmovisiones, de culto, de conciencia y de pensamiento de forma individual o colectiva, pública o privada; y el reconocimiento institucional de las organizaciones religiosas y de creencias espirituales en el Estado Plurinacional de Bolivia (artículo 1). Basándose en principios de pluralismo y coexistencia pacífica de las diversas religiones y creencias espirituales, 
ISSN 0719-7160

igualdad jurídica, no discriminación en razón de religión o creencias espirituales, cooperación entre el Estado y organizaciones religiosas y de creencias espirituales, y de respeto recíproco en el marco de la interculturalidad ${ }^{37}$.

\section{ECUADOR}

La actual Constitución Política del Ecuador también nace a través de un referéndum constitucional, llevado a efecto el año 2008. Anteriormente se mantenía vigente la Constitución de 1998, por tanto, estamos ante un proceso derogatorio de una Constitución que sólo alcanzó a existir en la vida del derecho unos años.

Esta Constitución también garantiza la libertad de culto o de religión y, en el mismo sentido que su par boliviana, lo hace a través de diversas disposiciones, partiendo por su artículo 1 que declara, dentro de sus principios fundamentales, que el Ecuador es un estado laico. Asimismo, agrega como un deber primordial del Estado el garantizar la ética laica como sustento del quehacer público y del ordenamiento jurídico (artículo $3 \mathrm{~N}^{\circ} 4$ ), y explicita que la educación pública es de carácter universal y laica (artículo 28). Sin embargo, evidentemente el hecho de que se sustente en una ética laica no impide una completa protección de los derechos asociados a la libertad de religión.

Su primer capítulo trata los principios de aplicación de los derechos, es decir, da ciertos principios a través de los cuales se deben ejercer los derechos que regula. Uno de ellos es el de igualdad y no discriminación, declarando que todas las personas son iguales y gozarán de los mismos derechos, deberes y oportunidades, y que en el estado de Ecuador nadie puede ser discriminado por razones de etnia, lugar de nacimiento, edad, sexo, identidad de género, identidad cultural, estado civil, idioma, religión, ideología, filiación política, pasado judicial, condición socio-económica, condición migratoria, orientación sexual, estado de salud, portar VIH, discapacidad, diferencia física; ni por cualquier otra distinción, personal o colectiva, temporal o permanente, que tenga por objeto o resultado menoscabar o anular el reconocimiento, goce o ejercicio de los derechos. Agrega como

\footnotetext{
37 Ley $N^{\circ} 1161$ de 16 de abril de 2019. Anteriormente, y aun cuando no existía esta ley, hubo diversas normas que permitieron el pluralismo religioso que consagra la Constitución. Así por ejemplo tenemos el Decreto Supremo 2369 del año 2015, que declaró prioridad e interés nacional la visita del Papa Francisco al Estado Plurinacional de Bolivia, del 8 al 10 de julio de 2015. También a modo de ejemplo podemos mencionar la ley $N^{\circ}$ 351 del año 2013 de otorgación de personalidades jurídicas, que permitió la personalidad jurídica a iglesias y agrupaciones religiosas y de creencias espirituales sin fines de lucro.
} 
Esteban Quiroz González \& Alexandra Maldonado Carvajal: Libertad de conciencia y religión en el proceso constituyente chileno.

deber del Estado el implementar medidas afirmativas que permitan promover de manera efectiva la igualdad de las personas (artículo 11).

Es importante destacar que en esta Constitución existe una sección destinada a tratar la comunicación e información (como aristas de la libertad de expresión), llamando la atención que el artículo 19 prohíbe explícitamente la emisión de publicidad que induzca a la violencia, la discriminación, el racismo, la toxicomanía, el sexismo, la intolerancia religiosa o política y toda aquella que atente contra los derechos. En este caso observamos una forma especial de protección, de rango constitucional y de manera anticipada o previa a (entre otras) la libertad religiosa, prohibiendo la intolerancia religiosa en la publicidad de los medios de comunicación, lo cual pugna en principio con otro derecho humano que es la libertad de expresión. Es decir, la protección al pluralismo religioso en esta Constitución parece estar bastante fortalecida, considerándose como una forma de discriminación a priori la intolerancia religiosa, sin existir una definición respecto de qué se trata al menos dentro de la propia Constitución.

Ya en lo específico, y en aquello que esta Constitución ha denominado "derechos de libertad" (o libertades), se reconoce y garantiza a las personas el derecho a practicar, conservar, cambiar, profesar en público o en privado su religión o sus creencias, y a difundirlas individual o colectivamente, con las restricciones que impone el respeto a los derechos. Es decir, las libertades de culto, religión o de conciencia tienen protección constitucional, sin más limitaciones que el respeto a los derechos ajenos. Asimismo, se señala que el Estado protegerá la práctica religiosa voluntaria, así como la expresión de quienes no profesan religión alguna, y favorecerá un ambiente de pluralidad y tolerancia (artículo $66 \mathrm{~N}^{\circ} 8$ ). En línea con esto último, también se garantiza el derecho a guardar reserva sobre las propias convicciones, y por lo tanto se prohíbe exigir o utilizar sin autorización del titular o de sus legítimos representantes, la información personal o de terceros sobre sus creencias religiosas, filiación o pensamiento político; ni sobre datos referentes a su salud y vida sexual, salvo por necesidades de atención médica (artículo 66 N¹1). En síntesis, esta Constitución permite practicar una religión de manera libre, difundirla, cambiarla, no profesar religión alguna, o guardar reserva sobre las propias convicciones personales, entre las cuales están por cierto las creencias religiosas, explicitando en el numeral 12 la objeción de conciencia.

En el mismo artículo relativo a las libertades (artículo $66 \mathrm{~N}^{\circ} 28$ ) se consagra el derecho a la identidad personal y colectiva, que incluye conservar, desarrollar y fortalecer las características 
ISSN 0719-7160

materiales e inmateriales de la identidad, destacando entre ellas las manifestaciones espirituales y religiosas.

La nueva Constitución ecuatoriana no modificó de manera sustancial la libertad de culto. Sí podemos destacar que agregó como principios constitucionales que el Estado es laico, y que éste debe someterse a una ética laica en su actuar, apareciendo explícitamente como una declaración de principios, sin perjuicio de que la Constitución anterior tampoco reconocía ninguna religión como oficial.

\section{VENEZUELA}

En el año 1999 Venezuela ve nacer una nueva Constitución Política, la cual viene a reemplazar a la Constitución de 1961. Esta nueva Constitución, también sometida a referéndum, es la vigente a la fecha de hoy.

Esta Constitución mantiene una visión sobre la libertad de conciencia y de religión similar a las de Bolivia y Ecuador.

En el mismo sentido que la Constitución ecuatoriana (la cual es posterior), la Constitución venezolana prohíbe los mensajes que promuevan la intolerancia religiosa, sindicándola como una forma de abuso de la libertad de expresión (artículo 57).

Además, dentro de los derechos civiles la Constitución regula la libertad de religión y de culto, señalando como obligación del Estado el garantizarlas. Agrega que toda persona tiene derecho a profesar su fe religiosa y cultos y a manifestar sus creencias en privado o en público, mediante la enseñanza u otras prácticas, siempre que no se opongan a la moral, a las buenas costumbres y al orden público. Se garantiza, así mismo, la independencia y la autonomía de las iglesias y confesiones religiosas, sin más limitaciones que las derivadas de la Constitución y de la ley. Se hace cargo también del derecho de dar enseñanza religiosa a los hijos, señalando que el padre y la madre tienen derecho a que sus hijos o hijas reciban la educación religiosa que esté de acuerdo con sus convicciones, y advierte que nadie podrá invocar creencias o disciplinas religiosas para eludir el cumplimiento de la ley ni para impedir a otro u otra el ejercicio de sus derechos (artículo 59). 
Esteban Quiroz González \& Alexandra Maldonado Carvajal: Libertad de conciencia y religión en el proceso constituyente chileno.

Por otra parte, y yéndonos nuevamente hacia la perspectiva de la religión como derecho colectivo, esta Constitución reconoce las religiones de los pueblos y comunidades indígenas como parte de su existencia (artículo 119), reconociendo su derecho a mantener y desarrollar su identidad étnica y cultural, cosmovisión, valores, espiritualidad y sus lugares sagrados y de culto.

Por último, se garantiza la libertad de conciencia y la posibilidad de manifestarla, pero acto seguido, señala que la objeción de conciencia no puede invocarse para eludir el cumplimiento de la ley o impedir a otros su cumplimiento o el ejercicio de sus derechos, lo cual hace que esta garantía quede restringida desde su origen, cuestión esta última que de hecho hereda de la carta fundamental anterior de 1961

Esto es, en términos generales, esta Carta regula la libertad religiosa en un sentido mucho más amplio que lo regulado en la Constitución de 1961, la cual trataba de manera muy escueta este derecho en su artículo 65, que sostenía que todos tienen derecho de profesar su fe religiosa y ejercitarla en público o en privado, siempre que esto no sea contrario al orden público o a las costumbres, agregando que nadie podrá invocar las creencias religiosas para eludir el cumplimiento de leyes ni impedir el ejercicio de sus derechos a otras personas. Incluso, la Constitución anterior mantenía una importante restricción adicional: el culto estaba sometido a la suprema inspección del Ejecutivo Nacional, de conformidad con la ley (artículo 65 inciso 2). Esta última disposición ya no existe en la actualidad. En ese sentido la actual Constitución es bastante más garantista respecto de la libertad religiosa, mejorando sus alcances.

\section{ARGENTINA}

El caso de Argentina es diferente, dado que su actual Constitución Política no nace a través de un proceso originario constituyente, sino que, a través de una reforma por la vía de una Convención Constituyente, esto es, la elección de representantes que habrían de realizar dicha reforma que vino a actualizar la antigua Constitución de 1853. Por tanto, su actual texto oficial es el de la Constitución sancionada en 1853, con las reformas de los años 1860, 1866, 1898, 1957 y 1994.

Por otra parte, cabe hacerse la pregunta sobre si Argentina es o no un estado confesional en virtud de diversas disposiciones que hacen mención a la religión católica apostólica y romana en su 
ISSN 0719-7160

Constitución vigente, que en su artículo 2 dice: El Gobierno federal sostiene el culto católico, apostólico, romano.

Esto era mucho más notorio antes de la reforma de 1994, tiempos en los que se mantenía en los mismos términos del artículo 2 ya mencionado, y además existían otras menciones explícitas a una idea teísta basada en el Dios cristiano: por ejemplo, la Constitución exigía dentro de los requisitos para ser presidente o vicepresidente de la nación el profesar la religión católica apostólica y romana (antiguo artículo 76), y al asumir el cargo debía jurar "por Dios y los Santos Evangelios", dejando "en manos de Dios y la Confederación" su eventual incumplimiento de sus deberes públicos (antiguo artículo 80). Sin embargo, actualmente el artículo 79 ya no exige profesar religión o fe alguna, y el juramento contenido en el actual artículo 93 explicita que se hará respetando las creencias religiosas de quién asuma el cargo de presidente y vicepresidente.

De todas maneras, llama la atención que estas obligaciones existieron en la Constitución desde su origen en 1853, manteniéndose en el tiempo y por tanto siendo exigibles a quienes quisieron gobernar el país por gran parte de su historia, realizándose la modificación recién en el año 1994, año en el que se permitió qué postularon a la presidencia personas que no profesan la religión católica apostólica romana, permitiendo en la práctica un avance desde un Estado que podríamos llamar confesional hacia uno aparentemente más laico.

Decimos aparentemente, dado que en la actualidad y a pesar de la reforma de 1994, se mantiene el artículo que señala que el Gobierno federal de la nación argentina sostiene el culto católico apostólico romano (artículo 2 ya mencionado), en concordancia con el espíritu de su preámbulo, en el cual se lee que el ejercicio constituyente se realizó "invocando la protección de Dios, fuente de toda razón y justicia". Es decir, si bien no se puede decir que hay una religión oficial en Argentina, en la Constitución tampoco se adhiere explícitamente a la idea de un estado laico, al contrario: siendo así la redacción se entiende que la Constitución prioriza esta religión por sobre otras. Sin perjuicio de las cuestiones históricas y fácticas que puedan explicar esta disposición, la Corte Suprema argentina ha resuelto ya que el culto católico no reviste el carácter de religión oficial del Estado, considerando en el año 1989 que los artículos ya mencionados "se relacionan íntimamente con costumbres y tradiciones legislativas del pueblo argentino y, también, fueron consecuencia de los derechos que el Estado ejerciera con motivo del Patronato [...] pero no significan, 
Esteban Quiroz González \& Alexandra Maldonado Carvajal: Libertad de conciencia y religión en el proceso constituyente chileno.

sin embargo que el culto católico apostólico romano revista el carácter de oficial del Estado y que, ineludiblemente, sus pautas confesionales deban ser consagradas en nuestra legislación positiva" ${ }^{38}$. Esto se condice (según el mismo fallo) con la historia de la ley, que deja en evidencia que, si bien la religión dominante era la católica, aquella no podría ser la religión del Estado pues no todos los habitantes ni todos los ciudadanos eran católicos ${ }^{39}$.

Es relevante preguntarse a qué se refiere la Constitución con "sostener el culto apostólico romano". La voz "sostener" ha sido discutida en la teoría constitucional Argentina, diferenciándose dos posturas: la primera, que considera el sustento como algo económico, "materializado en la inclusión de una partida para el clero secular en el presupuesto nacional"; y la segunda que amplía el sentido y alcance del término no sólo a lo económico, sino también a una obligación de "proteger y defender los dogmas y creencias católicos, y particularmente traducirlos en legislación y políticas específicas" ${ }^{\prime \prime}$. El mismo fallo ya señalado también se pronunció respecto del artículo 2 de la Constitución, refiriendo que éste "se limita a privilegiar a la Iglesia católica en sus relaciones con el Estado coadyuvando, a la vez, al sostén y protección económica de los gastos de ese culto, los cuales serían pagados por el tesoro nacional, incluidos en su presupuesto y sometidos, por consiguiente, al poder del Congreso".

Cabe destacar que la Corte Suprema, en diversos precedentes e incluso antes de $1994^{41}$, ha sostenido que ningún culto reviste el carácter de religión oficial del Estado argentino, lo cual al parecer ha quedado asentado en su jurisprudencia. Lo mismo pasa respecto al "sostenimiento" al que se refiere el artículo 2, el cual debe entenderse limitado al sostenimiento económico del culto católico, manteniéndose una posición neutral del Estado frente a las religiones ${ }^{42}$.

Este pluralismo religioso tendría consagración en el artículo 14 del capítulo que contiene las "declaraciones, derechos y garantías", y que garantiza a todos los habitantes de la Nación el derecho de profesar libremente su culto, reiterando en el artículo 20 que esta norma se hace aplicable a los extranjeros, quienes también podrán ejercer libremente su culto. Si bien no contiene una cláusula

38 CSJN, "Villacampa, Ignacio c/ Almos de Villacampa, María Angélica", sentencia del 09/02/1989. Fallos: 312:122. Disponible en: www.csjn.gov.ar.

39 Palabras del miembro informante de la comisión en el Congreso General Constituyente, Gorostiaga, citadas en el mismo caso "Villacampa, Ignacio c/ Almos de Villacampa, María Angélica".

40 (Gelli, 2018) en (El Estado argentino: ¿un Estado confesional o laico?, 2016 pág. 13)

${ }^{41}$ Afirmado en CSJN, "Castillo, Carina Viviana y otros c/ Provincia de Salta - Ministerio de Educación de la Prov. de Salta s/ amparo", sentencia del 12/12/2017. Fallos: 340:1795. Disponible en: www.csjn.gov.ar.

42 ídem 
ISSN 0719-7160

genérica de no discriminación, sí trata la igualdad en su artículo 16 Declarando que todos los habitantes de la nación son iguales ante la ley.

\section{CONCLUSIONES RESPECTO AL DERECHO COMPARADO}

Observados estos procesos constitucionales acaecidos en los últimos 26 años en Sudamérica, resulta evidente que más allá de lo perfeccionables que pudieran ser y de sus diversos contextos, estos siempre han presentado modificaciones al régimen de las libertades religiosas, siempre tendiente a proteger con mayor fuerza la libertad de religión y conciencia, eliminar o restringir la oficialidad de una religión en particular como la Católica (Bolivia y Ecuador) o limitar los controles del Estado sobre los diversos cultos (Venezuela). De esta manera se confirma la tendencia propia del derecho moderno y del régimen de derechos humanos a reconocer esta libertad fundamental a las personas, otorgando mayores libertades para lo autodeterminación religiosa y celebración del culto, eliminando discriminaciones o injerencias estatales en ella, siendo el caso argentino el único que mantuvo algunos elementos que vinculan al Estado con una religión particular.

\section{OTROS ANTECEDENTES: EL PROYECTO CONSTITUCIONAL DE BACHELET DE 2018}

Durante el segundo gobierno de la presidenta Michelle Bachelet existió una promesa de campaña relativa a la creación de una nueva Constitución Política, realizándose diversas instancias de participación ciudadana con este fin. Así, se presentó un proyecto de nueva Constitución que fue despachado al Congreso Nacional en los últimos días de su gobierno, por lo que finalmente no ha tenido mayor tramitación por carecer del apoyo del gobierno de turno entrante en el que salió electa la oposición encabezada por Sebastián Piñera.

A pesar de ello, junto con el proyecto que presentó para modificar la ley $N^{\circ} 19.638$ que también presentó en los últimos días de su mandato, se constituyen como un importante antecedente que se puede tener en cuenta para medir la naturaleza de la discusión en materia de libertad de conciencia y libertad religiosa en general en nuestro país, y que podemos resumir brevemente a continuación. 
Esteban Quiroz González \& Alexandra Maldonado Carvajal: Libertad de conciencia y religión en el proceso constituyente chileno.

El proyecto presentado mantiene en general la mayoría de los elementos de la Constitución del 80 heredados de la del 25, modificando el inciso primero en el sentido que agrega la objeción de conciencia como un elemento constitucional expreso, además que modifica el límite a la manifestación de todas las creencias y el ejercicio de todos los cultos, ya no en la "moral, las buenas costumbres o el orden público", sino solamente en "la ley", es decir, la limitación de dicho derecho solo puede ser establecido por el legislador al regular el mismo, y no puede ya invocarse la moral y las buenas costumbres. En ese sentido, entendemos que es una limitación menor a dicho derecho, con la especial garantía de estar reservado al legislador y no a elementos más abiertos, flexibles y fluctuantes como la moral y las buenas costumbres, entendiendo que, de hecho, en el orden público se encuentran las leyes mismas que pudieran dictarse. De esta forma, la limitación a este derecho en el proyecto parece más acotada, lo que puede beneficiar a ciertos cultos religiosos minoritarios numéricamente, por ejemplo, los indígenas.

En el inciso segundo se eliminan las palabras "de higiene y seguridad" en tanto única limitación legal y reglamentaria del levantamiento de templos para dar paso a una limitación legal y reglamentaria más general sin especificar, lo cual evidentemente aparece como un elemento de mayor coherencia para comprender los límites de edificación de templos en los que debe comprenderse no solo la cuestión de higiene y seguridad, sino otros elementos tales como los planes reguladores, la planificación urbana, el efecto ambiental y acústico, entre otras consideraciones, que a nuestro juicio, responden de forma más adecuada a la realidad de la construcción de edificaciones en Chile y de la que los templos no están exentos y no representa por tanto una restricción mayor en la práctica. Mientras que, en cuanto al inciso tercero, relativo a los bienes y la exención tributaria de contribuciones a los templos, permaneció exactamente igual, manteniendo el régimen de bienes y tributario tal y como está en la Constitución del 80 por herencia de la del 25.

En ese sentido, es manifiesto que el referido proyecto en realidad mantiene casi intacto el régimen constitucional, avanzando notablemente en el reconocimiento de la objeción de conciencia y realizando modificaciones que nos parecen amplían la libertad de conciencia o la hacen más coherente con la realidad nacional.

Aquello evidentemente da cuenta de una fuerte estabilidad de esta disposición constitucional en la tradición constitucional chilena, no pudiendo dudarse que dicho proyecto de ley, 
ISSN 0719-7160

aunque sea solo un proyecto sin soporte político por el Ejecutivo, podría tener influencia en el próximo proceso constitucional, como demuestra la experiencia de las discusiones legislativas.

Asimismo, dicho gobierno presentó una reforma en materia de la ley $N^{\circ} 19.638$ que es de gran interés para estos efectos, pues aventuró una definición de laicidad del Estado a través de una propuesta de modificación al artículo primero inciso final, señalando que debe ser "entendida como el mutuo respeto entre el Estado y las confesiones religiosas fundamentado en la autonomía de cada parte, y su deseable colaboración en las acciones coincidentemente orientadas por la consecución del bien común" (Artículo Único, numeral 1, letra b del Boletín 410-365 de 8 de marzo de 2018) como principio rector explícito para la ley, en conjunto con la libertad religiosa, la igualdad de las confesiones y entidades religiosas ante la ley ${ }^{43}$, por sobre un laicismo antirreligioso o hostil hacia el hecho religioso ${ }^{44}$.

Dichos elementos parecen relevantes para el fortalecimiento de la libertad religiosa y de lo que se ha denominado "laicidad cooperante" o "coordinada", recordando que en palabras del destacado jurista italiano Norberto Bobbio "el espíritu laico no es en sí mismo una nueva cultura, sino la condición para la convivencia de todas las culturas"45.

\section{CONCLUSIONES}

Hemos observado que el tema de la libertad de conciencia y religión no ha sido indiferente en nuestra historia constitucional chilena, sino que desde los albores de la República se manifestó como un asunto desafiante para el naciente Estado chileno independizado de la corona española, con diversas tensiones entre una perspectiva conservadora nacional católica versus la perspectiva republicana y liberal de corte progresista, tendiente a establecer la libertad de conciencia y religión además de la separación entre Iglesia y Estado.

\footnotetext{
${ }^{43}$ (Del Picó, 2013 pág. 11) ha señalado que existe "coincidencia general en cuanto a que deben ser considerados como tales el principio de no confesionalidad del Estado o de separación, según la perspectiva que se adopte, el principio de libertad religiosa, el principio de igualdad religiosa y el principio de cooperación".

${ }_{44}^{4}$ (Cavieres F, 2019 pág. 115)

${ }^{45}$ (Corral Salvador, 2011 pág. 454)
} 
Esteban Quiroz González \& Alexandra Maldonado Carvajal: Libertad de conciencia y religión en el proceso constituyente chileno.

Con la Constitución de 1925 el Estado chileno consagró la libertad de conciencia y la manifestación de todos los cultos como un derecho fundamental, consolidando un proceso de liberalización religiosa no exento de apasionada resistencia que forma en la actualidad parte firme de la tradición constitucional chilena, que fue heredada sin mayores modificaciones sustanciales en la Constitución de 1980 y que se vio fuertemente reforzada también por los instrumentos internacionales de derechos humanos y la dictación en el año 1999 de la ley N 19.638 sobre la constitución de la personalidad jurídica de las iglesias y confesiones religiosas, denominada ley de culto, que en cierta manera vinieron a corregir o complementar algunos defectos de las disposiciones constitucionales sobre la materia.

Hemos observado asimismo algunos antecedentes de contexto que nos permiten observar la naturaleza del proceso constitucional chileno que se vivirá en octubre de 2020, que nos permite tener en cuenta las garantías y espíritu de la reforma en materia de derechos fundamentales y hemos observado también cómo se ha dado esta discusión en el derecho comparado latinoamericano más reciente que ha realizado procesos constitucionales similares y en el último intento de dar lugar a una nueva Constitución en la postrimería del segundo gobierno de Michelle Bachelet luego de algunos procesos de participación ciudadana.

En este entendido, los antecedentes muestran una sólida presencia de la libertad de conciencia y de culto en nuestra tradición constitucional y también en el contexto regional, razón por la cual el proceso constitucional se muestra como una interesante posibilidad para consolidarla con mayor firmeza, fortaleciendo la autonomía y cooperación entre Estado y las diversas confesiones religiosas y estableciendo la clara libertad de los habitantes del territorio para profesar o no una religión en particular.

En dicho contexto, sabiendo la importancia de la libertad de conciencia en la configuración misma del derecho moderno, que algunos autores consideran parte incluso del origen mismo de la búsqueda de la dignidad humana y los derechos humanos ${ }^{46}$ y considerando que la sociedad chilena sigue siendo predominantemente religiosa y que la irreligiosidad o la indiferencia a la religión también es garantizada por la propia libertad de conciencia y religión, no parece previsible que se experimente un retroceso en la consagración de dicha libertad en el proceso constituyente, sino que se presenta

${ }^{46}$ (El concepto de libertad religiosa en algunos instrumentos internacionales sobre derechos humanos que vinculan jurídicamente al Estado de Chile, 2008) 
ISSN 0719-7160

la oportunidad de consolidar por la vía democrática su robusta concepción en la sociedad chilena, en el que la religión sigue formando parte de la cuestión y debate público con una vitalidad inesperada ${ }^{47}$. Por lo tanto, será esta ciudadanía con fuerte presencia religiosa la que -eligiendo a sus representantes y participando del proceso- deberá determinar sus reglas de convivencia y la conciliación de la ética de máximas religiosas con la ética de mínimos que demanda la convivencia jurídica en el derecho moderno ${ }^{48}$, reconociendo que dicho ejercicio, según constata la historia, no ha estado exento de episodios de intolerancia, integrismo y fundamentalismos poco compatibles con la democracia o comprometidos con la legitimación de tensas situaciones de poder contrarias a la dignidad humana y los derechos fundamentales, cuestión que sin lugar a dudas también se precisa tener en cuenta para la discusión del proceso constitucional venidero.

${ }^{47}$ (Habermas, 2015 pág. 265)

${ }^{48}$ (Cortina, 2002 pág. 117) 
Esteban Quiroz González \& Alexandra Maldonado Carvajal: Libertad de conciencia y religión en el proceso constituyente chileno.

\section{REFERENCIAS BIBLIOGRÁFICAS}

Bastías Saavedra, Manuel. 2013. Sociedad civil en dictadura. Santiago : Ediciones Universidad Alberto Hurtado, 2013. 978-956-9320-16-3.

Botto, Andrea. 2014. La separación Iglesia-Estado desde la perspectiva del catolicismo chileno (19231925). [aut. libro] Ana María Stuven. La religión en la esfera pública chilena: ¿laicidad o secularización? Santiago : Universidad Diego Portales, 2014.

Cavieres F, Eduardo. 2019. Iglesia, Estado y Sociedad. Valparaíso: Ediciones universitarias de la Pontificia Universidad Católica de Valparaíso, 2019. 978-956-17-0835-8.

Cid, Gabriel. 2014. Religión, legitimidad política y esfera pública en Chile: el tránsito de la monarquía a la república (1808-1833). [aut. libro] Ana María Stuven. La religión en la esfera púlica chilena: ¿laicidad o secularización? Santiago : Ediciones Universidad Diego Portales, 2014.

Corral Salvador, Carlos. 2011. Teología política. Una perspectiva histórica y sistemática. Valencia: Tirant Humanidades, 2011.

Cortina, Adela. 2002. Ética civil y religión. Madrid : PPC, 2002.

Del Picó, Jorge. 2013. Régimen legal de las iglesias y otras entidades religiosas. Santiago: Thomson Reuters, 2013. 978-956-346-396-5.

Derecho y religión en la primera legislación chilena posterior a la libertad de cultos (1925-1939): del Estado confesional a la laicidad realista. Salinas Araneda, Carlos. 2016. 38, Valparaíso : s.n., 2016, Revista de estudios histórico-jurídicos, Vol. XXXVIII.

El concepto de la tolerancia religiosa en Chile en la primera mitad del siglo XIX: a propósito de dos documentos diplomáticos británicos de 1854. González Pizarro, José Antonio. 2019. 2019, RDUCN [online], Vol. 26.

El concepto de libertad religiosa en algunos instrumentos internacionales sobre derechos humanos que vinculan jurídicamente al Estado de Chile. Badilla Poblete, Elvira. 2008. 2, Santiago : s.n., 2008, Revista Chilena de Derecho, Vol. 35. 
ISSN 0719-7160

El Estado argentino: ¿un Estado confesional o laico? Catanzaro Román, Mariana. 2016. 46, 2016, Anales de la Facultad De Ciencias Juridicas y Sociales de la Universidad Nacional de la Plata.

Gelli, María Angélica. 2018. Constitución de la Nación Argentina comentada y concordada. Buenos Aires: Thompson Reuters, 2018.

Habermas, Jürgen. 2015. Mundo de la vida, política y religión. Madrid : Trotta, 2015.

Iglesia Católica. 1884. Pastoral colectiva sobre relaciones entre Iglesia y Estado. Santiago : Imprenta del Correo, 1884.

Lagos Schuffeneger, Humberto. 2005. Chile y el mito del Estado laico. Santiago : Icthus, 2005. 9568366-02-4.

—. 1988. Crisis de la esperanza. Santiago : Presor-Lar, 1988.

-. 2009. La Herejía en Chile. Evangélicos y Protestantes desde la colonia hasta 1925. Santiago: Ediciones Sociedad Bíblica Chilena, 2009.

Lalive d'Epinay, Christian. 2010. El refugio de las masas. Estudio sociológico del protestantismo chileno. Santiago : CEEP Ediciones, 2010. 978-956-8052-06-5.

Los inicios del registro civil de Chile: ¿Ruptura o continuidad con las antiguas partidas eclesiásticas? Irarrázaval Gomién, Andrés. 2014. 36, Valparaíso : s.n., 2014, Revista de estudios histórico-jurídicos.

Ortiz Retamal, Juan Rodrigo. 2017. Historia de los evangélicos en Chile 1810-1891. Santiago: Parousia, 2017. 978-956-9650-01-7.

Pereira García, Oscar H. 2016. Presencia y arraigo protestante evangélico en Chile 1845-1925. Santiago : Ediciones Sociedad Bíblica Chilena, 2016. 978-956-9739-06-4.

Precht Pizarro, Jorge. 2006. Estudios sobre Libertad Religiosa en Chile. Santiago : Ediciones UC, 2006.

Ruiz-Tagle, Pablo. 2016. Cinco repúblicas y una tradición. Santiago : LOM, 2016. 978-956-00-0812-1.

Salinas C, Maximiliano. 1987. Historia del pueblo de Dios en Chile. Santigo : Rehue, 1987. 
Esteban Quiroz González \& Alexandra Maldonado Carvajal: Libertad de conciencia y religión en el proceso constituyente chileno.

Sepúlveda Rondanelli, Julio. 1993. Los radicales ante la historia. Santiago : Andres Bello, 1993.

Sobre el "Nuevo constitucionalismo latinoamericano". Gargarella, Roberto. 2018. 1, 2018, Rev. Urug. Cienc. Polít. [online], Vol. 27, págs. 109-129.

Stuven, Ana María. 2014. Desafíos a la confesionalidad del Estado chileno: religión y política, 18401883. La religión en la esfera pública chilena: ¿laicidad o secularización? Santiago: Ediciones Universidad Diego Portales, 2014.

-. 2014. La religión en la esfera pública chilena: ¿laicidad o secularización? Santiago: Ediciones Universidad Diego Portales, 2014. 978-956-314-266-2.

Trumbull, David. 1863. La lejislacion respecto a los matrimonios mistos juzgada a la luz de los intereses morales, políticos y relijiosos del país. Valparaíso : Imprenta del Universo de G. Helfmann, 1863.

Walker Martínez, Carlos. 1889. Historia de la Administración Santa María Tomo 1. Santiago : Imprenta de "El Progreso", 1889. 